\title{
Environmental behaviour of strontium in some salt affected soils along the Western North coast of Egypt \\ Doaa T. Eissa ${ }^{1}$ Ahmed M. Abou-Shady ${ }^{1 *}$ and Sahar M. Ismail ${ }^{1}$
}

\begin{abstract}
In the present work, $\mathrm{Sr}^{2+}$ contamination in some salt affected soils along the Western North coast of Egypt was investigated. The contamination of $\mathrm{Sr}^{2+}$ in different soils samples was evaluated using different risk indices such as enrichment factor (EF), geo-accumulation index $\left(I_{\text {geo }}\right)$, contamination factor (CF), the degree of contamination $\left(C_{d}\right)$, modified degree of contamination $\left(\mathrm{mC}_{\mathrm{d}}\right)$, pollution load index (PLI), soil pollution index (SPI), and ecological risk assessment (RAC). The concentrations of $\mathrm{Sr}^{2+}$ were investigated according to the bioaccumulation (BAC) in different plant species such as tomato (Solanum lycopersicum), leek (Allium ampeloprasum), barley (Hordeum vulgare), olive (Olea europaea), alfalfa (Medicago sativa), sweet sorghum (Sorghum vulgare var. sacchratum), fig ( Ficus carica), apple (Malus domestica), mountain spinach (Atriplex hortensis), onion (Allium cepa), eggplant (Solanum melongena), camphor (Cinnamomum camphora), faba bean (Vicia faba), galawein (Sonchus oleraceus L.), and orange (Citrus Sinensis). The obtained results showed that, the mean value of $\mathrm{EF}$ for $\mathrm{Sr}^{2+}$ was the highest (15) among the other associated elements. Although, the highest $I_{\text {geo }}$ values was observed with $\mathrm{Zn}^{2+}$ followed by $\mathrm{Cd}^{2+}$ and $\mathrm{Sr}^{2+}, \mathrm{Sr}^{2+}$ is not belongs to contamination category. According to $\mathrm{CF}$ index, $\mathrm{Sr}^{2+}$ is classified as low degree of contamination. According to $\mathrm{mC}_{\mathrm{d}}$ classification, $\mathrm{Sr}^{2+}$ contamination level is belongs to nil to very low degree of contamination class. The SPI presented that $\mathrm{Sr}^{2+}$ is considered moderate to highly contamination element. The highest values of BAC was found to be 2.018 in leek, while the lowest BAC value was 0.005 in tomato. To compare the concentration of median $\mathrm{Sr}$ in the studied area with its concentrations in the land of the African continent and the world, the median $\mathrm{Sr}$ in the western north coast of Egypt $(449 \mathrm{mg} / \mathrm{kg})$ appear to be very close to the empirical data value from Africa and higher than the empirical data value globally.
\end{abstract}

Keywords: Strontium; Contamination; Risk indices; Bioaccumulation

\section{INTRODUCTION}

Strontium $\left(\mathrm{Sr}^{2+}\right)$ pollution is considered a big dilemma nowadays, because of the increases concentration in wastewater and other areas (AbouShady, 2017). $\mathrm{Sr}^{2+}$ interference with the biological processes that normally involve calcium and eventually

${ }^{1}$ Laboratory of Water \& Soil Chemistry, Water Resources and Desert Soils Division, Desert Research Center, El-Matariya 11753,

Cairo, Egypt.

${ }^{*}$ Corresponding author. Tel. +201017442805

E-mail address: aboushady@ymail.com

Received March 13, 2018, Accepted April 26, 2018 skeletal development. The fact that $\mathrm{Sr}^{2+}$ is chemically similar to calcium allows it to exchange imperfectly with calcium in bone and other cellular that are enriched in calcium. Also, the function of different enzymes that are calcium dependent will be substituted when $\mathrm{Sr}^{2+}$ exists that may modify kinetic parameters. $\mathrm{Sr}^{2+}$ can interact with secondary cell messenger systems and transporter systems that normally use calcium (ATSDR, 2004).

At high doses of $\mathrm{Sr}^{2+}$, neurotoxic and neuromuscular perturbations may be caused. The total daily intake of $\mathrm{Sr}^{2+}$ for adults in many parts of the world is estimated to be up to $4 \mathrm{mg}$ day ${ }^{-1} . \mathrm{Sr}^{2+}$ occurs naturally in earth's crust (approximately $0.02-0.03 \%$ ) in mineral forms such as celestite (strontium sulfate) and strontianite (strontium carbonate). However, minor amounts of $\mathrm{Sr}^{2+}$ exist in other mineral deposits and close to sedimentary rocks associated with gypsum, anhydrite, rock salt, limestone, and dolomite. $\mathrm{Sr}^{2+}$ can also occur in shales, marls, and sandstones (ATSDR, 2004). low concentrations of the $\mathrm{Sr}^{2+}$ may be adsorbed on calcium carbonate via electrostatic attraction force as hydrate ions, however at high concentrations $\mathrm{Sr}^{2+}$ may be precipitated as strontianite (strontium carbonate) (Parkman et al., 1998).

The main objective of the present work was to investigate the environmental behavior of $\mathrm{Sr}^{2+}$ in some salt affected soils along Western North coast of Egypt. The transportation of $\mathrm{Sr}^{2+}$ from soil to the grown plants was also investigated. The contamination levels of $\mathrm{Sr}^{2+}$ concentrations were evaluated using risk indices such as enrichment factor $(\mathrm{EF})$, geo-accumulation index $\left(\mathrm{I}_{\mathrm{geo}}\right)$, contamination factor $(\mathrm{CF})$, the degree of contamination $\left(\mathrm{C}_{\mathrm{d}}\right)$, modified degree of contamination $\left(\mathrm{mC}_{\mathrm{d}}\right)$, pollution load index (PLI), soil pollution index (SPI), and risk assessment code (RAC). In addition, $\mathrm{Sr}^{2+}$ containing plants was investigated using bioaccumulation (BAC).

\section{MATERIALS AND METHODS}

Soil sampling and analysis:Soil samples were collected from different locations between latitude $27^{\circ}$ $2^{`} \mathrm{E}-29^{\circ} 55^{`} \mathrm{E}$ and $30^{\circ} 40^{`} \mathrm{~N}-31^{\circ} 22^{`} \mathrm{~N}$. These areas include different towns such as 


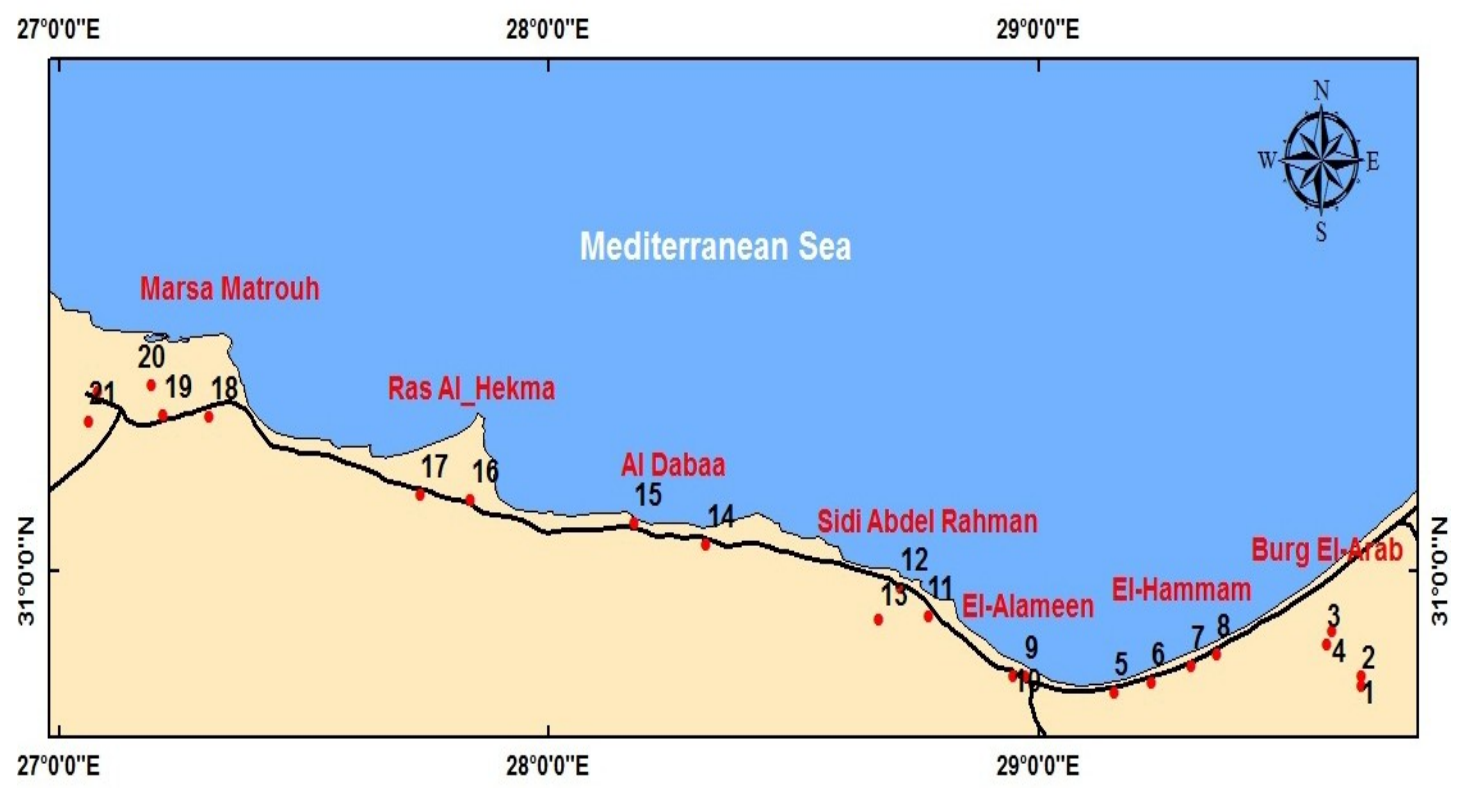

Fig. 1. A map shows the studied locations along the Western North Coast of Egypt

Burg El Arab, El Hammam, Al Alameen, Sidi Abdel Rahman, Al Dabaa, Ras Alhekma, and Marsa Matrouh. Forty three surface $(0-25) \mathrm{cm}$ and subsurface (25-50) $\mathrm{cm}$ soil samples were collected from 22 sites that represented calcareous soils along North Western Coastal Plain (Fig. 1). Sixty plant samples, grown in twenty one locations, representing the different plant species were collected.

Soil texture was determined using international pipette method. Organic matter content was determined according to Walkley and Black method. Soil $\mathrm{pH}$ was determined in the soil suspension of 1:2.5. Total soluble salts were determined in soil - water extract (1:2.5). Total carbonate content was determined using Collin's calcimeter method (Jackson, 1973). Heavy metals content was determined using Inductivity Coupled Argon Plasma (ICAP). $\mathrm{Sr}^{2+}$ fractions were determined using sequential extraction methods (Kilmer and Alexander, 1949, Piper, 1950, Jackson, 1973, Tessier et al., 1979, Jena et al., 2013).

\section{Plant analysis}

Plant samples (aerial parts and roots) were thoroughly washed with distilled water and dried at $70^{\circ}$ C. Afterwards, plant samples were digested using the mixture of $\mathrm{H}_{2} \mathrm{O}_{2}$ and $\mathrm{H}_{2} \mathrm{SO}_{4}$ according to Nicholson (1984).

\section{$\mathrm{Sr}^{2+}$ risk indices}

Enrichment factor (EF) : The EF was utilized to assess the level of contamination and possible anthropogenic impact of $\mathrm{Sr}^{2+}$ in the studied soils along the Western North Coast of Egypt. In the present study, Fe was used as the conservative tracer to differentiate natural components from the anthropogenic samples. The EF was calculated as follows according to Ergin et al.(1991), Abrahim and Parker (2008) and Chen et al. (2007):

$$
E F=\left(\frac{\left(C_{x} / C_{F e}\right)_{\text {sample }}}{(C x / C F e)_{\text {Re ference }}}\right)
$$

where $\left(\mathrm{C}_{\mathrm{x}} / \mathrm{C}_{\mathrm{Fe}}\right)_{\text {sample }}$ is the a ratio content of the element and $\mathrm{Fe}$ in the studied sample, and $\left(\mathrm{C}_{\mathrm{x}} / \mathrm{C}_{\mathrm{Fe}}\right)_{\text {Reference }}$ is the same ratio in the earth's crust Rudnick and Gao (2004) and Nadimi-Goki et al. (2014).

Geo-accumulation index $\left(\mathbf{I}_{\mathrm{geo}}\right)$ : Another approach to estimate the contamination levels of $\mathrm{Sr}^{2+}$ is the geoaccumulation index $\left(\mathrm{I}_{\mathrm{geo}}\right)$. This method assesses the degree of metal pollution in terms of seven enrichment classes based on the increasing numerical values of the index and could be calculated as follows according to Muller (1969) and Rudnick and Gao (2004):

$$
I_{\text {geo }}=\log _{2}\left(C_{x} / 1.5 b_{x}\right)
$$

where $C_{x}$ is the content of the element in the enriched samples, and $b_{x}$ is the background value of the element.

Contamination factor (CF): Contamination factor (CF) is the ratio of metal concentration in soil sample to its concentrations in the background. The $\mathrm{CF}$ was 
calculated using the following equation Hakanson (1980):

$$
C F=C_{x} / C_{r}
$$

where $C_{x}$ and $C_{r}$ are the mean concentrations of the metal contaminants in the soil samples and background reference material, respectively Chen et al.(2015).

The degree of contamination (Cd): The degree of contamination $\left(\mathrm{C}_{\mathrm{d}}\right)$ is based on the $\mathrm{CF}$ of the pollutant and may be calculated according to the following equation (Swarnalatha et al.(2015).

$$
C_{d}=\sum_{i=1}^{n} C F
$$

where $n$ is the number of analyzed elements and $i$ is $1^{\text {th }}$ element, and CF is the contamination factor.

Modified degree of contamination (mCd ): Abrahim and Parker (2008) presented a modified form for the Hakanson (1980) equation. The modified formula is generalized by defining the degree of contamination $\left(\mathrm{mC}_{\mathrm{d}}\right)$ as the sum of all the contamination factors $\left(\mathrm{C}_{\mathrm{d}}\right)$ for a given set of pollutants divided by the number of analyzed pollutants. The modified degree of contamination is given from the following equation:

$$
m C_{d}=\frac{\sum_{i=1}^{i=n} C F}{n}
$$

where $\mathrm{n}$ is the number of analyzed elements and CF is the contamination factor.

Pollution load index : To estimate the overall pollution status of the studied samples, the pollution load index (PLI) was calculated using the following equation Chen et al. (2015) and Qing et al. (2015).

$$
\mathrm{PLI}=\sqrt[n]{\left(C F_{1} \times C F_{2} \times C F_{3} \times C F_{4} \ldots \ldots . . \times C F_{n}\right.}
$$

where $\mathrm{CF}$ represents the contamination factor of a metal, and $\mathrm{n}$ represents the specific metals contamination factor.

Soil pollution index: Soil pollution index (SPI) is a simple well known pollution evaluation tool was used to identify single element contamination indices. SPI was calculated using the following equation:

$$
\mathrm{SPI}=\frac{\text { Metal content in soil }}{\text { Permissible level of metal in soil }}
$$

The permissible level of metals has been provided by soil quality guideline according to Gowd et al. (2010).
Environmental implications: The fractionation of metals is of critical issue because of their potential toxicity and mobility Maiz et al. (2000). The fractions that are most influenced by human activity include the exchangeable and carbonate-bound fractions, in which metals are weakly adsorbed and can become more bioavailable due to equilibration with the aqueous phase Rath et al. (2009). The reactivity of sediments was evaluated via applying the principles of the risk assessment code (RAC). The RAC is a scale that used to assess potential mobility and risk based on the percentage of exchangeable and carbonate-bound metal in the sediment Perin et al. (1985); Jain (2004); Ghrefat and Yusuf (2006) and Karak et al.(2011).

Strontium bioaccumulation in plant: The biological absorption coefficient (BAC) was used to characterize the degree of elements uptake by plants from soil. Nagaraju and Karimulla (2002) have defined the BAC as the ratio of concentration of an element in plant ash to the total metal concentrations in soils. On the other hand, Mountouris et al. (2002) and Hassinen et al. (2009) have defined the bioconcentration factor or translocation factor as the ratio of metal concentration in the edible part of vegetables such as leaves, seeds, and roots to the total metal concentrations.

\section{Statistical analysis}

For statistical analysis of the present data, both descriptive and multivariate data analysis was used, such as Cluster analysis, Factor analysis, and Principal Component Analysis. SPSS (SPSS 20.exe) were used to calculate the descriptive statistics (Min., Max., mean, Std. Deviation, median, skewness, kurtosis, factor analysis and Cluster analysis) and assess the elements' correlations with some soil parameters.

\section{RERSULTS AND DISCUSSION}

The present study dealt with environmental behavior of $\mathrm{Sr}^{2+}$ in some salt affected soils along the Western North Coast of Egypt. Tables (1a and ab) shows a summary of some physical and chemical properties for the investigated soils. In general, soil $\mathrm{pH}$ ranged from 7.0 to 8.9 denoting to the neutral to alkaline soil reaction. EC ranged from $0.20 \mathrm{dS} \mathrm{m}^{-1}$ to $12.21 \mathrm{dS} \mathrm{m}^{-1}$ indicating non-saline to extremely saline soil. Organic matter content ranged from $0.001 \%$ to $1.67 \%$. $\mathrm{CaCO}_{3}$ content ranged from $12.31 \%$ to $42.80 \%$. CEC ranged from $1.70 \mathrm{meq} 100 \mathrm{~g}^{-1}$ to $18.90 \mathrm{meq} 100 \mathrm{~g}^{-1}$. Percentage of sand fraction varied from $46.20 \%$ to $95.61 \%$ while clay content ranged from 2.68 to $32.80 \%$.

The risk indices were explicit to investigate the contamination degree of $\mathrm{Sr}^{2+}$ and other associated elements in the studied soils. The first risk indices was enrichment factor (EF). If the EF is higher than 1, the metal concentration in the soil sample will enrich 
Table 1a. the main physical and chemical properties of the studied soils

\begin{tabular}{|c|c|c|c|c|c|c|c|c|c|}
\hline & $\begin{array}{c}\mathrm{Sr}^{2+} \\
\left(\mu g^{-1}\right)\end{array}$ & PH & 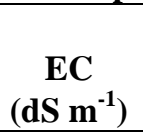 & $\begin{array}{l}\text { OM } \\
(\%) \\
\end{array}$ & $\begin{array}{c}\mathrm{CaCO}_{3} \\
(\%)\end{array}$ & $\begin{array}{c}\text { Sand } \\
(\%)\end{array}$ & $\begin{array}{l}\text { Silt } \\
(\%)\end{array}$ & $\begin{array}{l}\text { Clay } \\
(\%)\end{array}$ & $\begin{array}{c}\text { CEC } \\
\left(\operatorname{meq}_{1}\right)\end{array}$ \\
\hline Minimum & 159.1 & 7.00 & 0.20 & 0.001 & 12.31 & 46.2 & 1.71 & 2.68 & 1.7 \\
\hline Maximum & 740.0 & 8.91 & 12.21 & 1.67 & 42.8 & 95.61 & 22.4 & 32.8 & 18.9 \\
\hline Mean & 442.9 & 7.80 & 2.88 & 0.47 & 28.08 & 80.31 & 10.02 & 9.66 & 6.2 \\
\hline Median & 449.0 & 7.81 & 1.71 & 0.38 & 26.90 & 83.62 & 10.15 & 6.82 & 4.9 \\
\hline Std.Deviatio & & & & & & & & & \\
\hline $\mathrm{n}$ & 180.7 & 0.54 & 2.83 & 0.42 & 10.67 & 11.80 & 5.98 & 7.23 & 4.3 \\
\hline Skewness & -0.08 & 0.05 & 1.68 & 1.30 & -0.06 & -1.09 & 0.23 & 1.68 & 1.2 \\
\hline Kurtosis & -1.29 & -1.16 & 2.85 & 1.31 & -1.58 & 1.39 & -1.01 & 2.57 & 0.7 \\
\hline
\end{tabular}

Table 1b. the main physical and chemical properties of the studied soils

\begin{tabular}{|c|c|c|c|c|c|c|c|c|c|c|c|c|}
\hline & $\mathbf{F e}$ & Mn & $\mathbf{Z n}$ & $\mathrm{Cu}$ & Co & $\mathrm{Ni}$ & $\mathbf{P b}$ & $\mathrm{Cr}$ & $\mathbf{C d}$ & $\mathbf{C a}$ & Mg & $\mathbf{B a}$ \\
\hline & \multicolumn{12}{|c|}{$\left(\mu g^{-1}\right)$} \\
\hline Minimum & 10530.0 & 54.1 & 13.6 & 2.6 & 1.3 & 3.2 & 0.0 & 7.7 & 0.0 & $\begin{array}{l}22570.0 \\
191700 .\end{array}$ & 5909.0 & 4.3 \\
\hline Maximum & 59230.0 & 1010.0 & 608.1 & 38.1 & 33.2 & 64.2 & 7.6 & 136.1 & 3.1 & $\begin{array}{c}0 \\
102431 .\end{array}$ & 19680.0 & 40.3 \\
\hline Mean & 16318.6 & 197.7 & 100.0 & 11.0 & 5.9 & 16.5 & 2.5 & 28.9 & 0.2 & 9 & 12229.5 & 17.5 \\
\hline $\begin{array}{l}\text { Median } \\
\text { Std.Deviatio }\end{array}$ & 14925.0 & 145.4 & 52.1 & 9.4 & 4.1 & 14.5 & 1.9 & 22.6 & 0.1 & 97040.0 & 12320.0 & 15.8 \\
\hline $\mathrm{n}$ & 7151.3 & 155.7 & 110.4 & 7.0 & 5.4 & 12.2 & 2.1 & 23.1 & 0.5 & 38641.4 & 3019.1 & 9.9 \\
\hline Skewness & 5.4 & 3.6 & 2.7 & 2.1 & 3.3 & 2.2 & 1.3 & 2.9 & 5.7 & 0.2 & 0.2 & 0.5 \\
\hline Kurtosis & 32.4 & 17.4 & 9.8 & 5.4 & 15.2 & 6.0 & 0.9 & 10.8 & 34.5 & -0.3 & 0.4 & -0.7 \\
\hline
\end{tabular}

\section{Table 2. The Enrichment factor (EF) for $\mathrm{Sr}^{2+}$ and some associated elements in the studied soils}

\begin{tabular}{cccccc}
\hline Element & $\begin{array}{c}\text { Number of soil } \\
\text { samples }\end{array}$ & Minimum & Maximum & Mean & Std. Deviation \\
\hline $\mathrm{Ba}$ & 43 & 0.019 & 1.426 & 0.392 & 0.327 \\
$\mathrm{Sr}$ & 43 & 1.887 & 54.376 & 15.046 & 13.085 \\
$\mathrm{Cd}$ & 43 & 0.079 & 5.402 & 1.263 & 2.361 \\
$\mathrm{Co}$ & 43 & 0.405 & 2.265 & 1.752 & 0.234 \\
$\mathrm{Cr}$ & 43 & 0.905 & 5.831 & 1.396 & 0.778 \\
$\mathrm{Cu}$ & 43 & 0.470 & 3.921 & 1.033 & 0.580 \\
$\mathrm{Mn}$ & 43 & 0.523 & 2.140 & 1.242 & 0.284 \\
$\mathrm{Ni}$ & 43 & 0.480 & 3.690 & 0.946 & 0.622 \\
$\mathrm{~Pb}$ & 43 & 0.010 & 1.492 & 0.388 & 0.257 \\
$\mathrm{Zn}$ & 43 & 1.010 & 15.896 & 4.380 & 3.570 \\
\hline
\end{tabular}

\begin{tabular}{ccl}
\hline \multicolumn{2}{c}{ Table 3. Index of geoaccumulation $\left(\mathbf{I}_{\text {geo }}\right)$ for contamination levels in soil } \\
\hline $\mathbf{I}_{\text {geo }}$ & Class $\mathbf{I}_{\text {geo }}$ Value & \multicolumn{1}{c}{ Contamination Level } \\
\hline 1 & $0<\mathrm{I}_{\text {geo }}<1$ & Uncontaminated/moderately contaminated \\
2 & $1<\mathrm{I}_{\text {geo }}<2$ & Moderately contaminated \\
3 & $2<\mathrm{I}_{\text {geo }}<3$ & Moderately/strongly contaminated \\
4 & $3<\mathrm{I}_{\text {geo }}<4$ & Strongly contaminated \\
5 & $4<\mathrm{I}_{\text {geo }}<5$ & Strongly/extremely contaminated \\
6 & $5<\mathrm{I}_{\text {geo }}$ & Extremely contaminated \\
\hline
\end{tabular}

Mean values of the $I_{\text {geo }}$ for all elements which have been calculated and presented in Fig. 3 and table (4). This mean The $I_{\text {geo }}$ value of all elements remains in class ' 0 ', so the studied areas considered uncontaminated category.

soil values and the source of the metal in the topsoil is likely to be anthropogenic. On the other hand, when the EF values are less than 1, this indicates that the metal concentration is not enriched and may be related to the natural source. If the EF values are equal to 1, this indicates that metal concentration and its reference 
relative to the average of continental crust and surface

value are the same Swarnalatha et al. (2015). The EF values for $\mathrm{Sr}^{2+}$ and some associated elements are presented in Table (2). The maximum values of the EF was observed with $\mathrm{Sr}^{2+}$ and $\mathrm{Zn}^{2}$, respectively compared with that was observed with the other associated elements. This may be owing to the fact that $\mathrm{Sr}^{2+}$ is strongly associated with calcium and indicative calcareous rocks. It is clear that there is no enrichment risk for $\mathrm{Ba}, \mathrm{Co}, \mathrm{Cr}, \mathrm{Cu}$, $\mathrm{Mn}, \mathrm{Ni}$, and $\mathrm{Pb}$. The lowest values of $\mathrm{EF}$ were observed with $\mathrm{Pb}^{2+}$ followed by $\mathrm{Ba}<\mathrm{Cd}<\mathrm{Co}<\mathrm{Cu}<\mathrm{Ni}<\mathrm{Mn}<$ $\mathrm{Cr}<\mathrm{Zn}<$ Sr, Fig. (2).

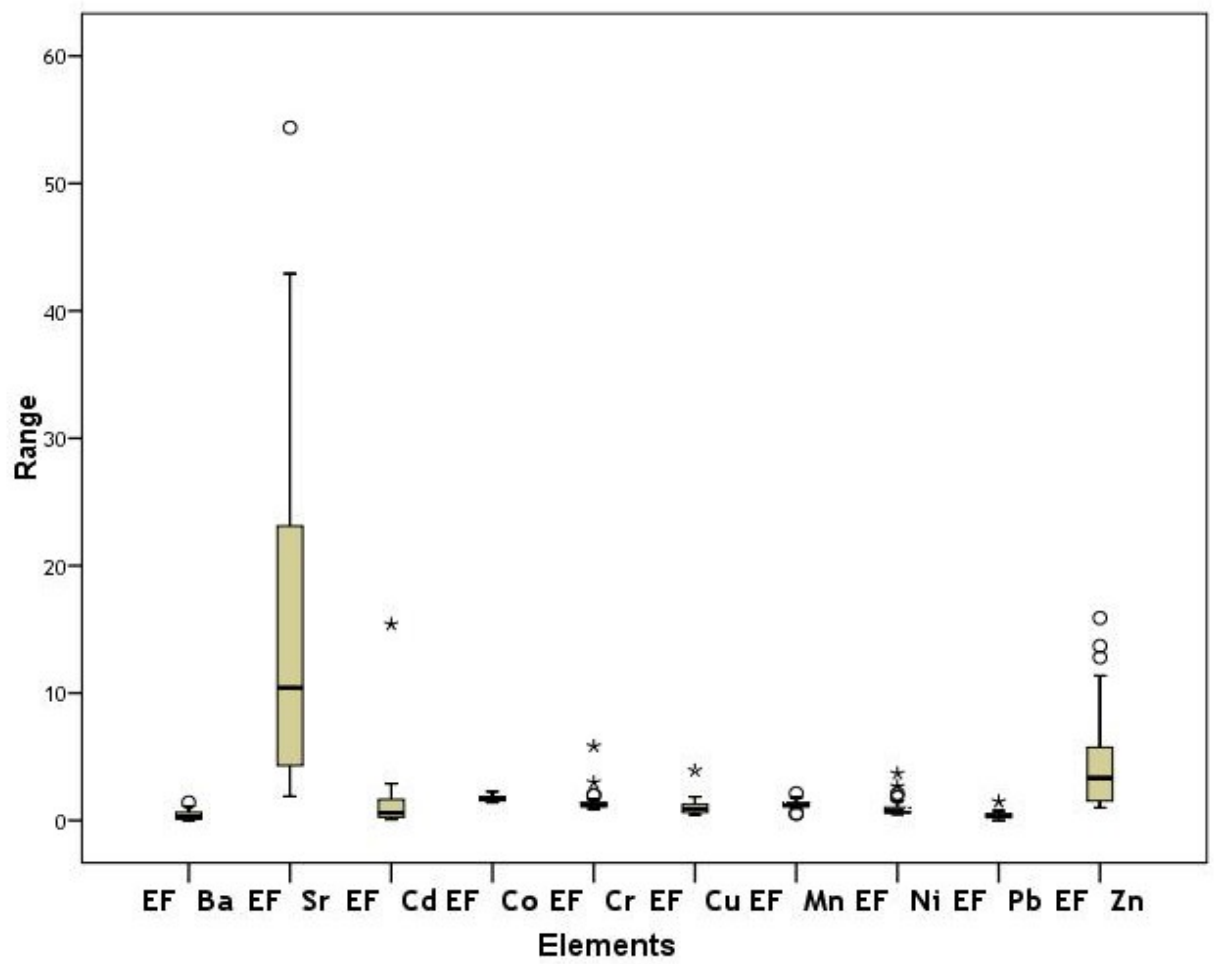

Fig. 2. Enrichment factors for some element in the studied soils

Table 4. Indexes of geo-accumulation (Ig) for some elements concentrations in the studied soils

\begin{tabular}{cccccc}
\hline Element & $\begin{array}{c}\text { Number of soil } \\
\text { Samples }\end{array}$ & Minimum & Maximum & Mean & Std. Deviation \\
\hline $\mathrm{Ba}$ & 43 & -7.31 & -4.08 & -5.55 & 0.92 \\
$\mathrm{Sr}$ & 43 & -1.59 & 0.62 & -0.26 & 0.68 \\
$\mathrm{Cd}$ & 43 & -7.46 & 0.83 & -4.28 & 1.65 \\
$\mathrm{Co}$ & 43 & -4.50 & 0.15 & -2.75 & 1.07 \\
$\mathrm{Cr}$ & 43 & -4.77 & -0.64 & -3.17 & 0.89 \\
$\mathrm{Cu}$ & 43 & -5.49 & -1.64 & -3.66 & 0.82 \\
$\mathrm{Fe}$ & 43 & -3.26 & -0.76 & -2.69 & 0.38 \\
$\mathrm{Mn}$ & 43 & -4.88 & -0.65 & -3.28 & 0.85 \\
$\mathrm{Ni}$ & 43 & -5.89 & -1.55 & -3.82 & 0.95 \\
$\mathrm{~Pb}$ & 43 & -10.75 & -3.17 & -5.31 & 1.52 \\
$\mathrm{Zn}$ & 43 & -4.10 & 1.39 & -1.84 & 1.32 \\
\hline
\end{tabular}

Table 5. the terminologies used to describe the contamination factor CF (Hakanson et al., 1980)

\begin{tabular}{lll}
\hline $\mathbf{C F}$ & $\mathbf{C}_{\mathbf{d}}$ & Description \\
\hline $\mathrm{CF}<1$ & $\mathrm{C}_{\mathrm{d}}<7$ & Low degree of contamination \\
$1<\mathrm{CF}<3$ & $7<\mathrm{C}_{\mathrm{d}}<14$ & Moderate degree of contamination \\
$3<\mathrm{CF}<6$ & $14<\mathrm{C}_{\mathrm{d}}<28$ & Considerable degree of contamination \\
$\mathrm{CF}>6$ & $\mathrm{C}_{\mathrm{d}}>28$ & Very high degree of contamination \\
\hline
\end{tabular}


Mean of all $\mathrm{CF}$ values is less than 1 except mean value of $\mathrm{CF}$ for $\mathrm{Sr}$ is (1.38), which indicated that $\mathrm{CF}$ for $\mathrm{Ba}, \mathrm{Cd}, \mathrm{Co}, \mathrm{Cr}, \mathrm{Cu}, \mathrm{Fe}, \mathrm{Mn}, \mathrm{Ni}, \mathrm{Pb}$ and $\mathrm{Zn}$ are low contamination but $\mathrm{CF}$ for $\mathrm{Sr}$ only is moderate contamination. Value $\mathrm{C}_{\mathrm{d}}$ ranged from 1.50 to 11.35 and its mean value is 3.49 i.e. this value less than 7 so its description is low degree of contamination, Table (5 and 6) and Fig. (4).

For the classification and description of the $\mathrm{mC}_{\mathrm{d}}$ seven gradations are proposed as shown in Table (7).

$\mathrm{mC}_{\mathrm{d}}$ is ranged from 0.14 to 1.03 and its mean equal to 0.317 ,i.e. this less than 1.5 . so the class of modified degree of contamination level is nil to very low degree of contamination, Table (7).
The pollution load index values are used to classify samples as; unpolluted (PLI $\leq 1)$, moderately polluted (PLI $=1-3)$, highly polluted (PLI = 3-5) or very highly polluted (PLI > 5) (Qing et al., 2015). The pollution load index has been calculated and ranged from 0.06 to 0.54 and its mean is 0.163 , i.e. it less than 1 ,so can classify as unpolluted.

The soil pollution index level of each heavy metal present was classified as low contamination (SPI $\leq 1)$, moderate contamination $(1<\mathrm{SPI} \leq 3)$ or high contamination (SPI > 3) (Chen et al., 2005). All calculated values of SPI for all elements except SPI of $\mathrm{Sr}$ and $\mathrm{Zn}$ is less than 1. So the pollution index levels of $\mathrm{Ba}, \mathrm{Cr}, \mathrm{Cu}, \mathrm{Pb}$ and $\mathrm{Zn}$ are low contamination and while SPI of $\mathrm{Sr}$ is moderate contamination, Table (8) and Fig. (5).

Table 6. Contamination factors for some elements the in studied soils

\begin{tabular}{lccccc}
\hline Element & Number of soil samples & Minimum & Maximum & Mean & Std. Deviation \\
\hline $\mathrm{Ba}$ & 43 & 0.009 & 0.088 & 0.038 & 0.022 \\
$\mathrm{Sr}$ & 43 & 0.497 & 2.313 & 1.384 & 0.565 \\
$\mathrm{Cd}$ & 43 & 0.009 & 2.658 & 0.172 & 0.409 \\
$\mathrm{Co}$ & 43 & 0.067 & 1.660 & 0.295 & 0.269 \\
$\mathrm{Cr}$ & 0.055 & 0.965 & 0.205 & 0.164 \\
$\mathrm{Cu}$ & 43 & 0.033 & 0.483 & 0.139 & 0.088 \\
$\mathrm{Fe}$ & 0.157 & 0.883 & 0.243 & 0.107 \\
$\mathrm{Mn}$ & 43 & 0.051 & 0.953 & 0.186 & 0.147 \\
$\mathrm{Ni}$ & 0.025 & 0.513 & 0.132 & 0.097 \\
$\mathrm{~Pb}$ & 43 & 0.001 & 0.166 & 0.055 & 0.045 \\
$\mathrm{Zn}$ & 43 & 0.088 & 3.923 & 0.645 & 0.712 \\
\hline
\end{tabular}

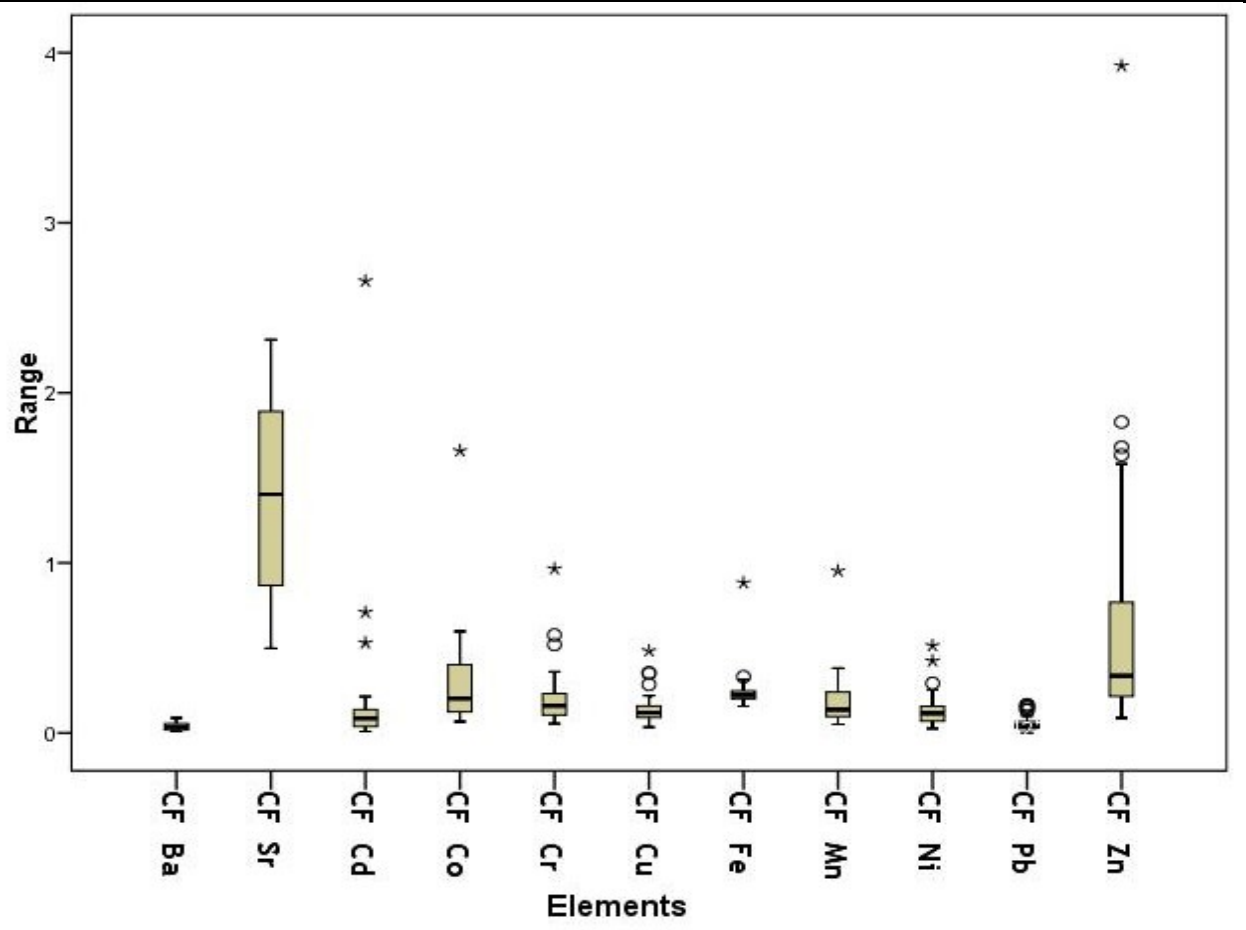

Fig.4. Contamination factor for metals in the studied soils 
Table 7. Different modified degree of contamination $\left(\mathrm{mC}_{\mathrm{d}}\right)$ for soil

\begin{tabular}{ll}
\hline \multicolumn{1}{c}{$\mathbf{m C}_{\mathbf{d}}$ Class } & \multicolumn{1}{c}{$\begin{array}{c}\text { Modified Degree of } \\
\text { Contamination Level }\end{array}$} \\
\hline $\mathrm{mC}_{\mathrm{d}}<1.5$ & Nil to very low \\
$1.5 \leq \mathrm{mC}_{\mathrm{d}}<2$ & Low \\
$2 \leq \mathrm{mC}_{\mathrm{d}}<4$ & Moderate \\
$4 \leq \mathrm{mC}_{\mathrm{d}}<8$ & High \\
$8 \leq \mathrm{mC}_{\mathrm{d}}<16$ & Very high \\
$\mathrm{mC}_{\mathrm{d}} \geq 32$ & Extremely high \\
$16 \leq \mathrm{mC}_{\mathrm{d}}<32$ & Ultra high \\
\hline
\end{tabular}

\section{Correlation analysis:}

Significant correlation was found among trace element concentrations and some physco-chemical properties, especially $\mathrm{Sr} / \mathrm{Ca}(\mathrm{r}=0.60)$ That agree with the fact $\mathrm{Sr}$ and $\mathrm{Ca}$ have similar ionic radii and other research suggesting that $\mathrm{Sr}$ and $\mathrm{Ca}$ are associated mostly with the mineral phase in soils, $\mathrm{Sr} / \mathrm{Ba}(\mathrm{r}=0.48), \mathrm{Sr} / \mathrm{Co}$ $(\mathrm{r}=-0.35), \mathrm{Sr} / \mathrm{pH} \quad(\mathrm{r}=-0.42), \mathrm{Sr} / \mathrm{OM} \quad(\mathrm{r}=0.37)$ and $\mathrm{Sr}$ $/ \mathrm{CaCO}_{3} \quad(\mathrm{r}=-0.38)$. Almost trace elements were

\begin{tabular}{cccccc}
\hline Element & $\begin{array}{c}\text { Number of soil } \\
\text { samples }\end{array}$ & Minimum & Maximum & Mean & $\begin{array}{c}\text { Std. } \\
\text { Deviation }\end{array}$ \\
\hline $\mathrm{Ba}$ & 43 & 0.009 & 0.081 & 0.035 & 0.020 \\
$\mathrm{Sr}$ & 43 & 0.796 & 3.700 & 2.215 & 0.904 \\
$\mathrm{Cr}$ & 43 & 0.121 & 2.127 & 0.451 & 0.361 \\
$\mathrm{Cu}$ & 43 & 0.042 & 0.605 & 0.175 & 0.111 \\
$\mathrm{~Pb}$ & 43 & 0.000 & 0.055 & 0.018 & 0.015 \\
$\mathrm{Zn}$ & 43 & 0.068 & 3.041 & 0.500 & 0.552 \\
\hline
\end{tabular}

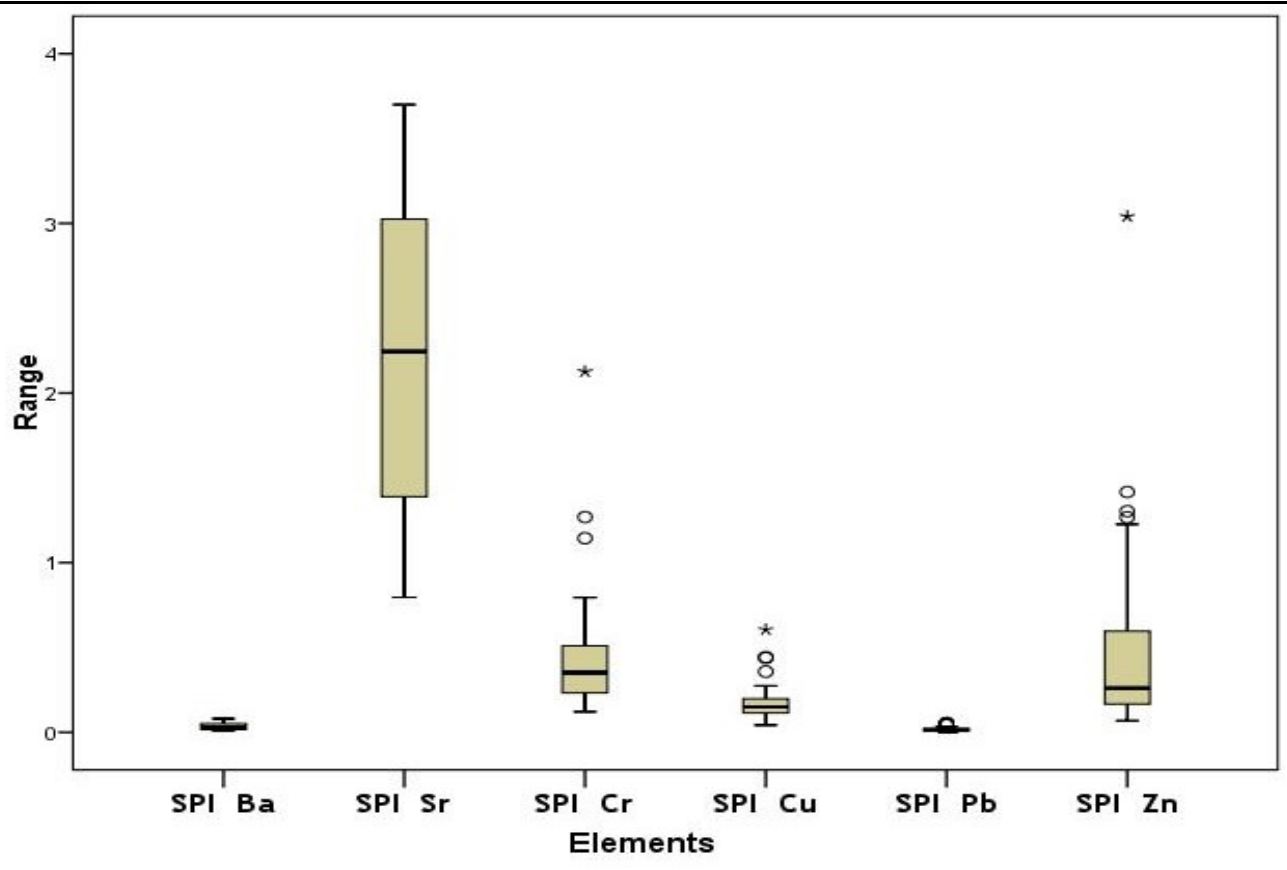

Fig.5. Soil pollution Indexes for metals in the studied soils 


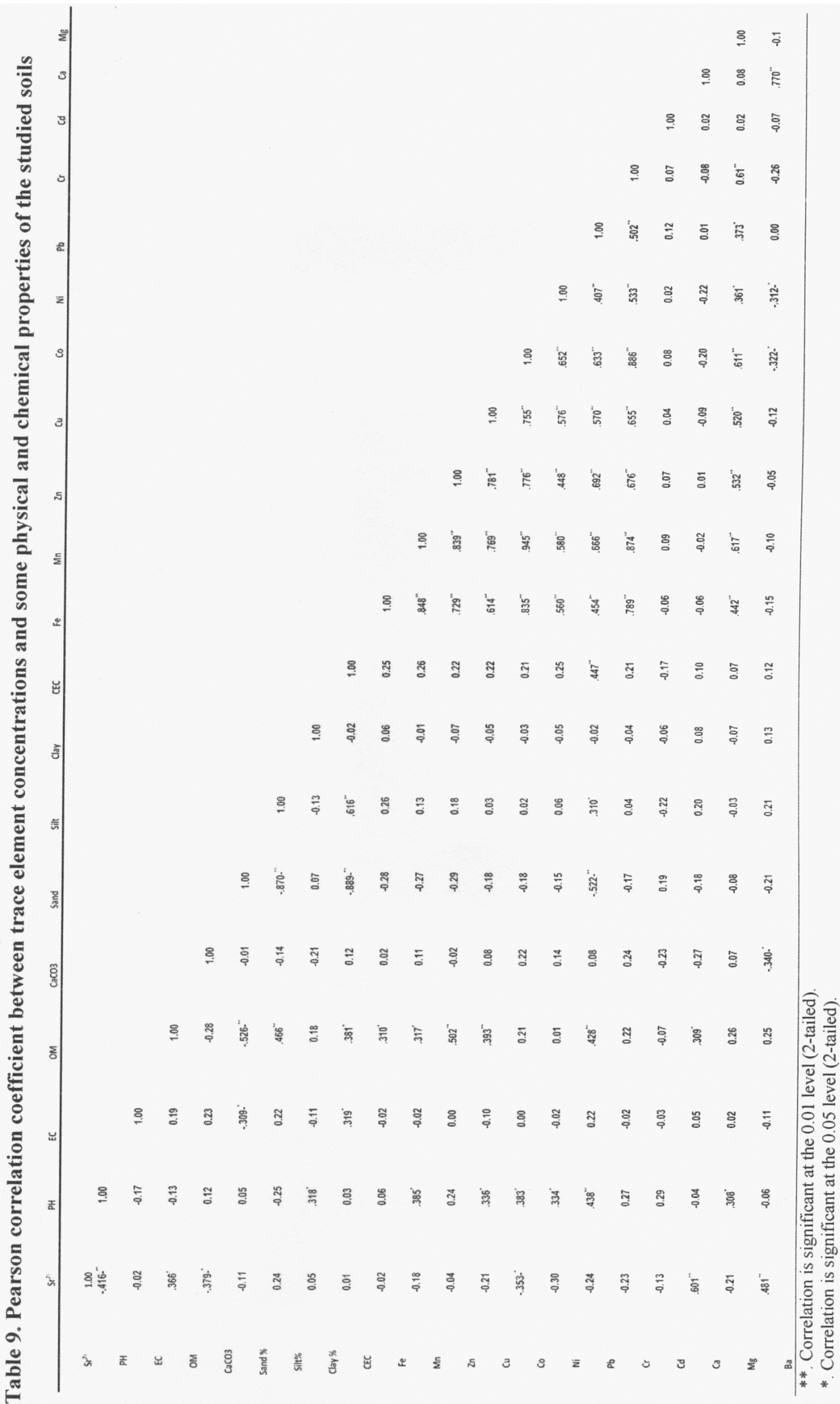


Table 10. Total variance explained and component matrices for the heavy metals

\begin{tabular}{|c|c|c|c|c|c|c|c|c|c|}
\hline \multirow{2}{*}{ Component } & \multicolumn{3}{|c|}{ Initial Eigenvalues } & \multicolumn{3}{|c|}{$\begin{array}{c}\text { Extraction Sums of Squared } \\
\text { Loadings } \\
\end{array}$} & \multicolumn{3}{|c|}{ Rotation Sums of Squared Loadings } \\
\hline & Total & $\begin{array}{c}\% \text { of } \\
\text { Variance }\end{array}$ & $\begin{array}{c}\text { Cumulative } \\
\%\end{array}$ & Total & $\begin{array}{c}\% \text { of } \\
\text { Variance }\end{array}$ & $\begin{array}{r}\text { Cumul } \\
\text { ative \% }\end{array}$ & Total & $\begin{array}{c}\% \text { of } \\
\text { Variance }\end{array}$ & Cumulative \% \\
\hline 1 & 6.379 & 49.073 & 49.073 & 6.379 & 49.073 & 49.073 & 6.186 & 47.588 & 47.588 \\
\hline 2 & 2.243 & 17.255 & 66.328 & 2.243 & 17.255 & 66.328 & 2.422 & 18.632 & 66.220 \\
\hline 3 & 1.071 & 8.242 & 74.570 & 1.071 & 8.242 & 74.570 & 1.086 & 8.350 & 74.570 \\
\hline 4 & 0.738 & 5.679 & 80.248 & & & & & & \\
\hline 5 & 0.705 & 5.420 & 85.668 & & & & & & \\
\hline 6 & 0.555 & 4.267 & 89.935 & & & & & & \\
\hline 7 & 0.429 & 3.297 & 93.232 & & & & & & \\
\hline 8 & 0.344 & 2.644 & 95.876 & & & & & & \\
\hline 9 & 0.212 & 1.628 & 97.504 & & & & & & \\
\hline 10 & 0.126 & .972 & 98.476 & & & & & & \\
\hline 11 & 0.102 & .786 & 99.262 & & & & & & \\
\hline 12 & 0.074 & .572 & 99.834 & & & & & & \\
\hline 13 & 0.022 & .166 & 100.000 & & & & & & \\
\hline \multicolumn{4}{|c|}{ Component Matrixa } & \multicolumn{5}{|c|}{ Rotated Component Matrixa } & \\
\hline & \multicolumn{3}{|c|}{ Component } & & \multicolumn{3}{|c|}{ Component } & & \\
\hline & PC1 & PC2 & PC3 & & PC1 & & PC2 & PC3 & \\
\hline Co & 0.970 & $\begin{array}{c}- \\
0.059\end{array}$ & -0.015 & & 0.968 & & -0.029 & 0.048 & \\
\hline Mn & 0.954 & 0.174 & & & 0.935 & & -0.262 & 0.035 & \\
\hline $\mathrm{Cr}$ & 0.886 & 0.035 & -0.055 & & 0.886 & & 0.075 & 0.067 & \\
\hline $\mathrm{Zn}$ & 0.853 & 0.258 & 0.034 & & 0.874 & & -0.154 & -0.012 & \\
\hline $\mathrm{Fe}$ & 0.837 & 0.152 & -0.243 & & 0.860 & & -0.037 & -0.206 & \\
\hline $\mathrm{Cu}$ & 0.834 & 0.089 & & & 0.833 & & -0.087 & 0.041 & \\
\hline $\mathrm{Pb}$ & 0.698 & 0.149 & 0.264 & & 0.702 & & 0.011 & 0.292 & \\
\hline $\mathrm{Ni}$ & 0.694 & $\begin{array}{c}- \\
0.193\end{array}$ & -0.097 & & 0.675 & & -0.015 & 0.048 & \\
\hline $\mathrm{Mg}$ & 0.665 & 0.126 & 0.020 & & 0.641 & & -0.337 & -0.057 & \\
\hline $\mathrm{Ca}$ & -0.16 & 0.901 & 0.127 & & 0.023 & & 0.921 & 0.088 & \\
\hline $\mathrm{Ba}$ & -0.278 & 0.834 & 0.091 & & -0.099 & & 0.877 & 0.050 & \\
\hline $\mathrm{Sr}$ & -0.315 & 0.722 & -0.218 & & -0.146 & & 0.762 & -0.257 & \\
\hline $\mathrm{Cd}$ & 0.082 & $\begin{array}{c}- \\
0.071\end{array}$ & 0.926 & & 0.027 & & -0.047 & 0.931 & \\
\hline
\end{tabular}

Factor analysis to reduce the number of variables, a factor analysis was applied to the available data set by using Principal Component Analysis (PCA) and cluster analysis (CA) were used to distinguish the different groups of heavy metals. PCA with varimax rotation was performed with respected factor loadings were calculated using eigen values $>1$. The factor loadings may be classified as 'strong', 'moderate' and 'week' considering their significant influence in the geochemical processes corresponding to absolute loading values of > 0.70, $0.70-0.50$ and $0.50-0.40$, respectively (Liu et al., 2003; Panda et al., 2006). In the current study factor analysis separate the soil analysis data into three factors, which describe the distribution of elements in the studied soils. These factors explain
$74.5 \%$ of the variance using 13 variables in the analysis .The results of PCA for heavy metal contents are listed in Table (10).

According to these results, $\mathrm{Sr}, \mathrm{Ca}, \mathrm{Ba}, \mathrm{Co}, \mathrm{Mn}, \mathrm{Cr}$, $\mathrm{Zn}, \mathrm{Fe}, \mathrm{Cu}, \mathrm{Pb}$, and $\mathrm{Ni}$. $\mathrm{Mg}$ and $\mathrm{Cd}$ concentrations could be grouped into a three component model, the first principal component (PC1) was correlated with $\mathrm{Co}, \mathrm{Mn}$, $\mathrm{Cr}, \mathrm{Zn}, \mathrm{Fe}, \mathrm{Cu}, \mathrm{Pb}, \mathrm{Ni}$ and $\mathrm{Mg}$. The second principal component (PC2) includes $\mathrm{Sr}, \mathrm{Ca}$ and $\mathrm{Ba}$. While $\mathrm{Cd}$ was only isolated in the third component (PC3). The result of CA analysis is illustrated in the dendrogram (Fig.6). Three distinct clusters can be identified Cluster I contained $\mathrm{Sr}, \mathrm{Ca}$ and $\mathrm{Ba}$. While the long distance between $\mathrm{Cd}$ and the other heavy metals may suggest that this cluster can be further divided into two sub 
clusters Cluster II contained $\mathrm{Sr}, \mathrm{Ca}$ and $\mathrm{Ba}$. The results of PCA agreed well with that of the CA. Therefore, it is suggested from the PCA and CA that the analysed elements may be classified into three groups.

\section{Ecological risk assessment:}

The exchangeable and carbonate bound metals easily mobile and thereby make themselves more readily bio-available (Singh et al., 2005). The criteria of risk assessment code (RAC) as given below indicates that the soil that can release $<1 \%$ of the total metal in exchangeable and carbonate fractions is considered safe, i.e. in no risk category while that release $>50 \%$ of the total metal in the same fraction is considered to be under very high risk category. Low risk is there when the release is $1-10 \%$, medium risk is there when the release is $11-30 \%$, high risk is there when the release is $31-50 \%$ and very high risk (>50\%) (Perin et al., 1985). Mean of RAC is 69.237, 69.889, 70.606, 67.289, 72.021, 71.970 and 68.680 in Burg El Arab, El Hammam, Al Alameen, Sidi Abdl Rahman, Al Dabaa, Ras Alhekma, and Marsa Matrouh area respectively, indicating their significant bio-availability which may pose significant ecological risk, (RAC> 50\%). Strontium content ratio of F1-soluble fraction is ranged from 0.155 to 0.367 , its ratio of $\mathrm{F} 2$-exchangeable fractionis ranged from 9.88 to 20.03 , its ratio of F3carbonate fraction is ranged from 47.06 to 63.452 , its ratio of F4-bound to Fe-Mn oxyhydroxides (Fe-Mn-) ranged from 18.54 to 33.80 , its ratio of F5-bound to organic matter (OM-) ranged from 0.954 to 4.953 and its content ratio of F6-residual (Res-) ranged from 0.953 to 3.673 , Table (11)

\section{Bioaccumulation of strontium (BAC):}

The BAC has a wide range (0.001-100), which could be classified into five groups; Nagaraju and Karimulla (2002), very weak absorption 0.001-0.01; weak absorption $0.01-0.1$; intermediate absorption $0.1-$ 1; strong absorption 1-10; intensive absorption 10-100. The BAC of strontium in study area was calculated and the results were shown in Table (12), the classification of BAC could be ordered as follows: very weak absorption (1.66\%), weak absorption (16.66\%), intermediate absorption (76.66\%) and strong absorption (5\%), The variation of BAC was not remarkable in different districts, which due to the bio-available contents of strontium were similar in different districts. Furthermore, the highest BAC (2.018) was occurred in Leek (Allium ampeloprasum) and the lowest BAC (0.005) was occurred in tomato (Solanum lycopersicum). The highest $\mathrm{Sr} / \mathrm{Ca}$ (0.257) was occurred in Sweet sorghum (Sorghum vulgare var. sacchratum) and the lowest $\mathrm{Sr} / \mathrm{Ca}(0.006)$ was occurred in Olive (Olea europaea). Although the concentration of $\mathrm{Sr}$ is considered value but its absorption by all the plants was significantly limited that due to their specific absorption comparing to their $\mathrm{Ca}$ absorption.

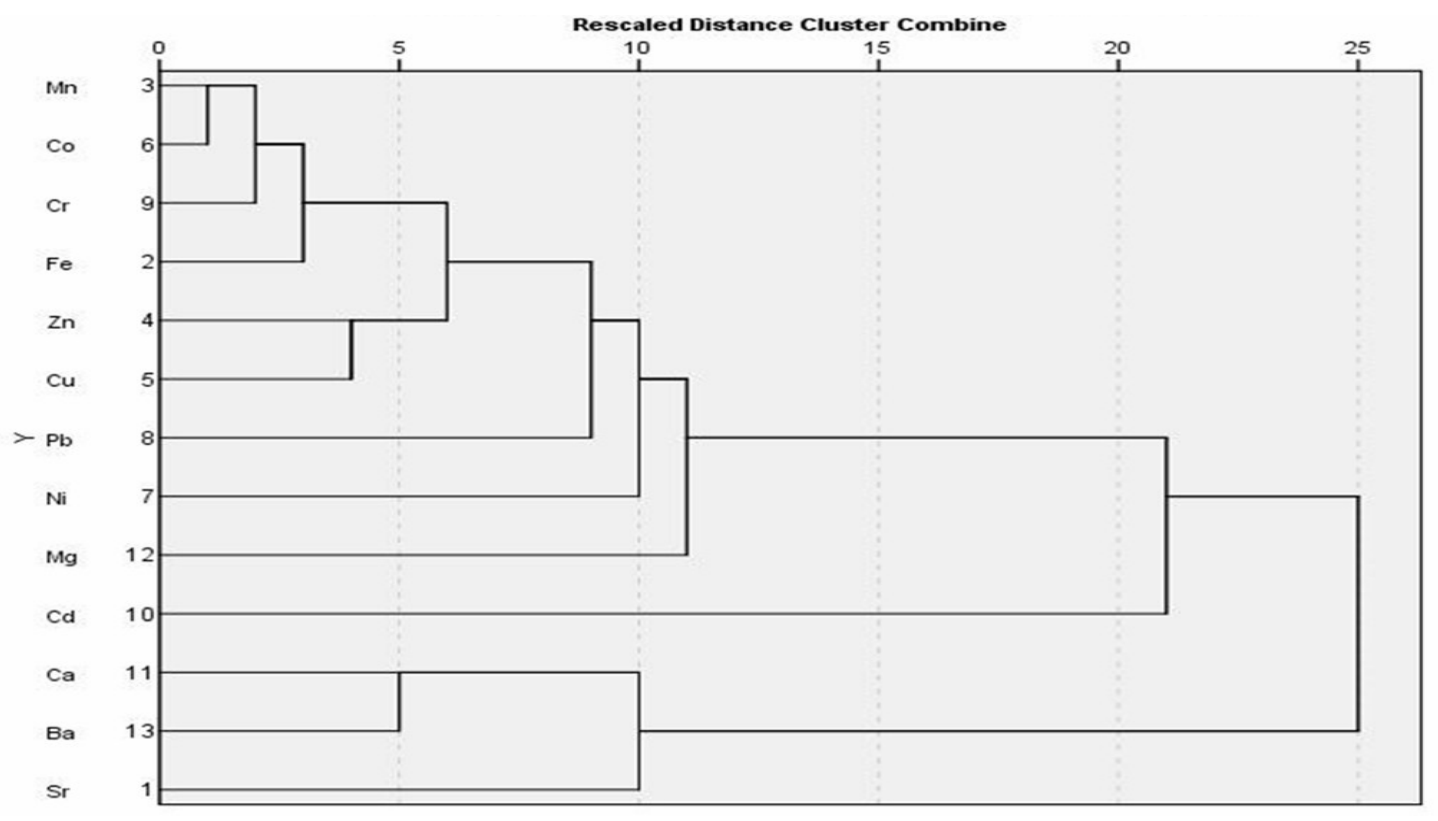

Fig.6. Dendrogram depicting the hierachical clustering of the heavy metals 
Table 11. Ratio of $\mathrm{Sr}$ in different fractions and RAC in the studied areas

\begin{tabular}{|c|c|c|c|c|c|}
\hline Location & & Minimum & Maximum & Mean & Std. Deviation \\
\hline \multirow{7}{*}{ Burg EL Arab } & F1 \% & 0.161 & 1.302 & 0.531 & 0.390 \\
\hline & $\mathrm{F} 2 \%$ & 12.548 & 17.664 & 14.675 & 1.671 \\
\hline & F3 $\%$ & 48.251 & 59.456 & 54.562 & 5.161 \\
\hline & $\mathrm{F} 4 \%$ & 18.960 & 33.414 & 25.642 & 6.575 \\
\hline & F5 \% & 1.524 & 4.754 & 2.892 & 1.523 \\
\hline & F6 \% & 1.061 & 2.379 & 1.698 & 0.589 \\
\hline & RAC & 60.799 & 75.783 & 69.237 & 6.512 \\
\hline \multirow{7}{*}{ El-Hammam } & F1 \% & 0.166 & 0.720 & 0.363 & 0.218 \\
\hline & $\mathrm{F} 2 \%$ & 11.361 & 20.038 & 16.529 & 3.286 \\
\hline & $\mathrm{F} 3 \%$ & 47.060 & 56.821 & 53.361 & 3.592 \\
\hline & $\mathrm{F} 4 \%$ & 21.451 & 29.075 & 25.210 & 2.437 \\
\hline & F5 \% & 1.375 & 4.943 & 2.439 & 1.367 \\
\hline & F6 \% & 1.509 & 2.721 & 2.098 & 0.391 \\
\hline & RAC & 66.443 & 74.276 & 69.889 & 2.411 \\
\hline \multirow{7}{*}{ Al-Alameen } & $\mathrm{F} \%$ & 0.294 & 0.983 & 0.534 & 0.309 \\
\hline & $\mathrm{F} 2 \%$ & 12.574 & 16.178 & 14.560 & 1.746 \\
\hline & F3 \% & 49.103 & 60.509 & 56.046 & 5.486 \\
\hline & $\mathrm{F} 4 \%$ & 19.123 & 33.055 & 25.178 & 5.907 \\
\hline & F5 \% & 1.011 & 2.105 & 1.543 & 0.482 \\
\hline & F6 \% & 1.901 & 2.424 & 2.139 & 0.215 \\
\hline & RAC & 62.727 & 76.374 & 70.606 & 5.799 \\
\hline \multirow{7}{*}{ Sidi AbdlRahman } & F1 \% & 0.179 & 0.835 & 0.532 & 0.232 \\
\hline & $\mathrm{F} 2 \%$ & 11.464 & 17.972 & 13.680 & 2.682 \\
\hline & F3\% & 47.650 & 62.214 & 53.610 & 6.559 \\
\hline & $\mathrm{F} 4 \%$ & 21.978 & 33.854 & 27.388 & 4.683 \\
\hline & F5 \% & 1.742 & 4.478 & 3.202 & 1.182 \\
\hline & F6 \% & 0.953 & 2.213 & 1.589 & 0.501 \\
\hline & RAC & 59.624 & 74.656 & 67.289 & 5.397 \\
\hline \multirow{7}{*}{ AlDabaa } & F1 \% & 0.181 & 0.610 & 0.341 & 0.189 \\
\hline & $\mathrm{F} 2 \%$ & 10.865 & 17.376 & 13.821 & 3.050 \\
\hline & F3 \% & 54.486 & 59.867 & 58.201 & 2.534 \\
\hline & $\mathrm{F} 4 \%$ & 18.547 & 24.858 & 22.753 & 2.861 \\
\hline & F5 \% & 2.047 & 2.470 & 2.325 & 0.194 \\
\hline & F6 \% & 1.456 & 3.272 & 2.560 & 0.844 \\
\hline & $\mathrm{RAC}$ & 69.790 & 76.061 & 72.022 & 2.793 \\
\hline \multirow{7}{*}{ Ras Alhekma } & F1 \% & 0.154 & 0.367 & 0.274 & 0.109 \\
\hline & $\mathrm{F} 2 \%$ & 11.157 & 16.917 & 12.953 & 2.671 \\
\hline & F3 \% & 53.576 & 63.452 & 59.022 & 4.859 \\
\hline & $\mathrm{F} 4 \%$ & 19.910 & 26.317 & 23.002 & 2.789 \\
\hline & F5 \% & 1.927 & 2.814 & 2.236 & 0.415 \\
\hline & F6 \% & 2.059 & 3.673 & 2.514 & 0.779 \\
\hline & RAC & 67.912 & 75.565 & 71.975 & 3.436 \\
\hline \multirow{2}{*}{ Marsa Matrouh } & F1 \% & 0.209 & 0.590 & 0.402 & 0.119 \\
\hline & $\mathrm{F} 2 \%$ & 9.886 & 15.920 & 11.691 & 2.198 \\
\hline
\end{tabular}


Table 11. Continued

\begin{tabular}{lccccc}
\hline Location & & Minimum & Maximum & Mean & Std. Deviation \\
\hline & F3 \% & 49.872 & 62.615 & 56.991 & 4.351 \\
F4 \% & 21.723 & 33.800 & 26.870 & 4.585 \\
F5 \% & 0.954 & 4.953 & 2.149 & 1.086 \\
F6 \% & 1.048 & 2.266 & 1.897 & 0.361 \\
RAC & 59.758 & 73.482 & 68.682 & 4.560 \\
\hline
\end{tabular}

$\overline{\text { Strontium content in F1-soluble fraction, F2-exchangeable fraction,F3-carbonate fraction, F4-bound to Fe-Mn oxyhydroxides (Fe- }}$ Mn-), F5-bound to organic matter (OM-), and F6-residual (Res-)

Table 12. Strontium content (ppm) in plants and calculated BAC in study areas

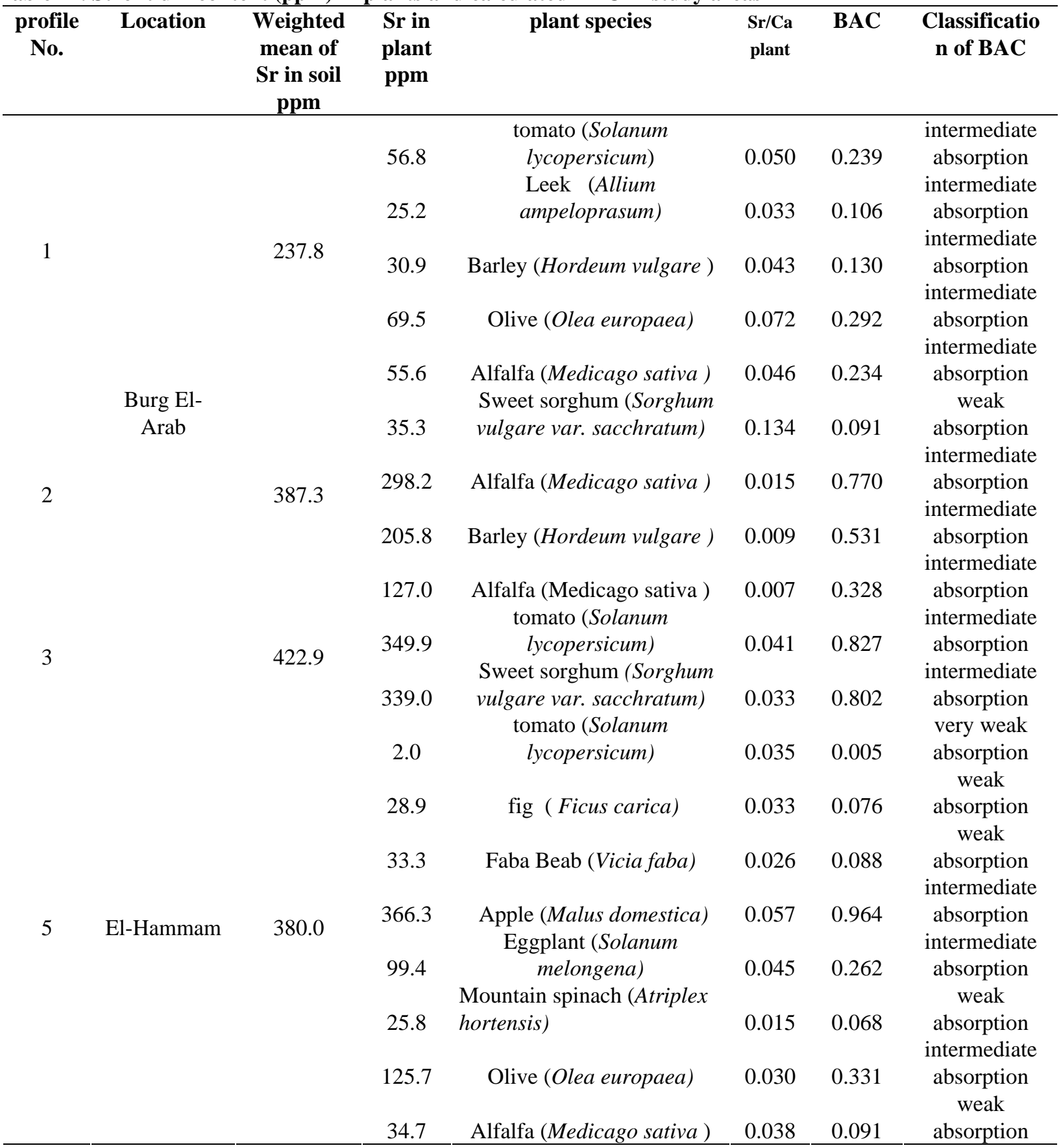


Table 12. Continued

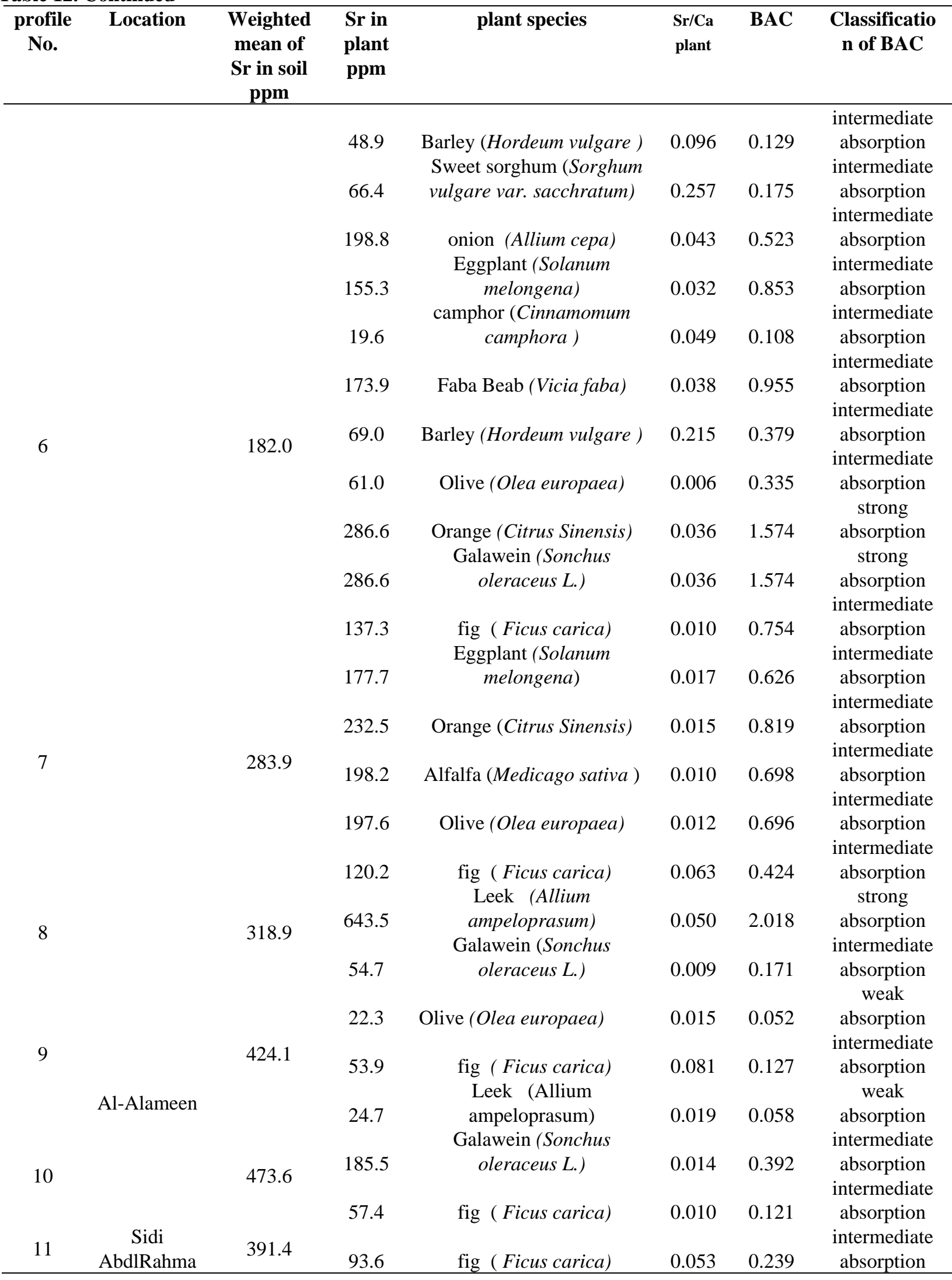




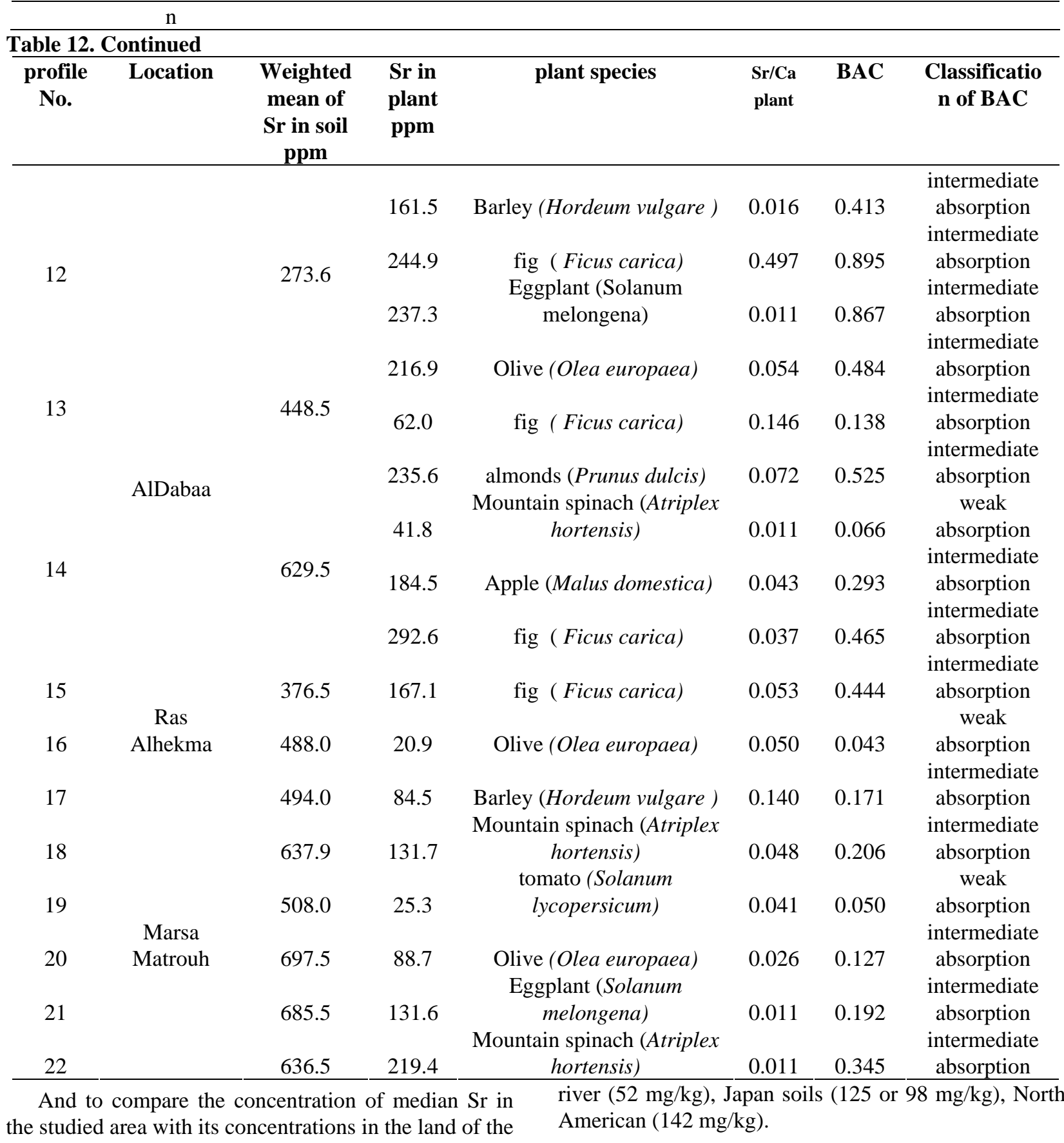
African continent and the world, table (13)

The median $\mathrm{Sr}$ in the western north coast of Egypt (449 $\mathrm{mg} / \mathrm{kg}$ ) appear to be significantly above empirical data from both Nile Delta $(263 \mathrm{mg} / \mathrm{kg})$ and soil Egyptian central Nile Valley $(307 \mathrm{mg} / \mathrm{kg}$ ) and value is very close to the value of Aswan-Sohag (400 mg/kg), Aswan-Asyut valley (214 $\mathrm{mg} / \mathrm{kg})$ and Africa (47 $\mathrm{mg} / \mathrm{kg}$ ). The median $\mathrm{Sr}$ in the western north coast of Egypt was less than its value globally, England and Wales $(27 \mathrm{mg} / \mathrm{kg}$ ), North Germany (9 mg/kg), North Europe $(15 \mathrm{mg} / \mathrm{kg})$, Whole Europe $(89 \mathrm{mg} / \mathrm{kg}$ ), Congo

\section{CONCLUSIONS}

$\mathrm{Sr}^{2+}$ contamination in some salt affected soils along the Western North coast of Egypt was investigated. The contamination of $\mathrm{Sr}^{2+}$ in different soils samples was evaluated using different risk indices such as EF, $\mathrm{I}_{\text {geo }}$, $\mathrm{CF}, \mathrm{C}_{\mathrm{d}}, \mathrm{mC}_{\mathrm{d}}, \mathrm{PLI}, \mathrm{SPI}$, and RAC. The concentrations of $\mathrm{Sr}^{2+}$ in deferent plant species were also investigated according to the bioaccumulation (BAC) for different plant species such as tomato, leek, barley, olive, alfalfa, sweet sorghum, fig, apple, mountain spinach, onion, 
eggplant, camphor, faba bean, galawein, and orange.

The obtained results showed that, the mean value of EF

Table 13. Comparison of $\mathrm{Sr}^{2+}$ median values $\left(\mathrm{mg} \mathrm{kg}^{-1}\right)$ in the present work and the obtained data from other relevant literature

\begin{tabular}{|c|c|c|}
\hline $\begin{array}{l}\text { Median } \\
\text { (mg/kg) }\end{array}$ & Location & Reference \\
\hline 449 & the western north coast of Egypt & The present study \\
\hline \multirow[t]{2}{*}{263} & Nile Delta & Arafa et al., (2015) \\
\hline & soil Egyptian central Nile & \\
\hline 307 & Valley & Badawy et al., (2017) \\
\hline 214 & Aswan-Asyut vally & Arafa et al., (2015) \\
\hline 400 & Aswan-Sohag & Dekov et al. (1997) \\
\hline 47 & Africa & Towett et al., (2015) \\
\hline 27 & England and Wales & Mc Grath and Loveland (1992). \\
\hline 9 & North Germany & Reimann et al. (2003). \\
\hline 15 & North Europe & Reimann et al. (2003). \\
\hline 89 & Whole Europe & Salminen (2005). \\
\hline 73.7 & Central Catalonia & Tume et al., (2011) \\
\hline 375 & Crustal Average & Kabata-Pendias and Mukherjee (2007). \\
\hline 147 & various soils & Kabata-Pendias and Mukherjee (2007). \\
\hline 52 & Congo river & Dupre et al., (1996) \\
\hline 125 & Agricultural soils in Japan & Yanai et al., (2012) \\
\hline 98 & Japan soils & Takeda (2004) \\
\hline $32-1000$ & Reported worldwide range & Kabata-Pendias and Mukherjee (2007). \\
\hline 117 & Upper Niger & Picouet et al., (2002) \\
\hline 350 & Upper continental crust & Rudnick and Gao, (2004), \\
\hline 175 & various soils & Gromet et al., (1984) \\
\hline 187 & various soils & Viers et al. (2009) \\
\hline 142 & $\begin{array}{c}\text { North American } \\
\text { Shale Composite (NASC) }\end{array}$ & Earthref, (2013) \\
\hline 175 & world average soil (WAS & Kabata-Pendias (2011) \\
\hline 250 & Soil of the world & Bowen (1979) \\
\hline
\end{tabular}

for $\mathrm{Sr}^{2+}$ was the highest (15) among the other associated elements. Although, the highest $\mathrm{I}_{\text {geo }}$ values was observed with $\mathrm{Zn}^{2+}$ followed by $\mathrm{Cd}^{2+}$ and $\mathrm{Sr}^{2+}, \mathrm{Sr}^{2+}$ is not belongs to contamination category. According to $\mathrm{CF}$ index, $\mathrm{Sr}^{2+}$ is classified as low degree of contamination. According to $\mathrm{mC}_{\mathrm{d}}$ classification, $\mathrm{Sr}^{2+}$ contamination level is belongs to nil to very low degree of contamination class. The SPI presented that $\mathrm{Sr}^{2+}$ is considered moderate to highly contamination element. The highest values of BAC was found to be 2.018 in Leek, while the lowest BAC value was 0.005 in tomato.

\section{ACKNOWLEDGMENTS}

This work was supported by Desert Research Center, Research No: 1822.

\section{REFERENCES}

Abou-Shady, A. 2017. Recycling of polluted wastewater for agriculture purpose using electrodialysis: Perspective for large scale application. Chem. Engine. J. 323: 1-18.
Abrahim, G.M.S. and J. Parker. 2008. Assessment of heavy metal enrichment factors and the degree of contamination in marine sediments from Tamaki Estuary, Auckland, New Zealand. Environ. Monit. Assess. 136: 227-238.

Arafa, W.M., Badawy, W.M., Fahmi, N.M., Ali, K., Gad, M.S., Duliu, O.G., Frontasyeva, M.V. and E. Steinnes. 2015. Geochemistry of sediments and surface soils from the Nile Delta and lower Nile valley studied by epithermal neutron activation analysis. Journal of African Earth Sciences 107: 57-64.

ATSDR. 2004. Toxicological profile for strontium. Atlanta, GA, United States Department of Health and Human Services, Public Health Service, Agency for Toxic Substances and Disease Registry (http://www.atsdr.cdc.gov/toxprofiles/ tp159.html.

Badawy, W.M., Ghanim, E.H., Duliu, O.G., El Samman, H. and V. Frontasyeva. 2017. Major and trace element distribution in soil and sediments from the Egyptian central Nile Valley. Journal of African Earth Sciences. 131: 53-61.

Bowen, H.J.M (Ed.). 1979: Environmental Chemistry of the Elements. Academic Press Inc. Ltd., London. 
Chen, C.W., Kao, C.M., Chen, C.F. and C. Di Dong, 2007. Distribution and accumulation of heavy metals in the sediments of Kaohsiung Harbor, Taiwan. Chemosphere 66: $1431-1440$.

Chen, H., Teng, Y., Lu, S., Wang, Y. and J. Wang. 2015. Contamination features and health risk of soil heavy metals in China. Sci. Total. Environ. 512: 143-153.

Dekov, V.M., Komy, Z., Araujo, F., Van Put, A. and R. Vann Grieken. 1997. Chemical composition of sediments, suspended matter, river water and ground water of the Nile (Aswan-Sohag traverse). Sci. Total. Environ. 201 (13): 195-210.

Dupre, B., Gaillardet, J., Rousseau, D. and J. All-Egre. 1996. Major and trace elements of river-borne material: the Congo Basin. Geochim. Cosmochim. Acta 60: 1301-1321.

Earthref, 2013. GERM Reservoir Database, $<$ http://earthref.org/GERMRD/842/>.

Edinburg: CEP Consultants.

Ergin, M., Saydam, C., Bas, Türk, O., Erdem, E. and R. Yorük. 1991. Heavy metal concentrations in surface sediments from the two coastal inlets (Golden Horn Estuary and _Izmit Bay) of the northeastern Sea of Marmara. Chem. Geol. 91:269-285.

Ghrefat, H. and N. Yusuf. 2006. Assessing Mn, $\mathrm{Fe}, \mathrm{Cu}, \mathrm{Zn}$, and $\mathrm{Cd}$ pollution in bottom sediments of Wadi Al-Arab Dam, Jordan. Chemosphere. 65: 2114-2121.

Gowd, S., Ramakrishna Reddy, M. and K. Govil. 2010. Assessment of heavy metal contamination in soils at Jajmau (Kanpur) and Unnao industrial areas of the Ganga Plain, Uttar Pradesh, India. Journal of Hazardous Materials. 174: 113-121.

Gromet, L.P., Haskin, L.A., Korotev, R.L. and F. Dymek. 1984. The "North American shale composite": its compilation, major and trace element characteristics. Geochim. Cosmochim. Acta. 48: 2469-2482.

Hakanson, L. 1980. An ecological risk index for aquatic pollution control. A sedimentological approach. Water Res. 14 (8): 975-1001.

Hassinen, V., Vallinkoski, V. M., Issakainen, S., Tervahauta, A., K?renlampi, S. and K. Jackson, M. L. 1973. Soil Chemical Analysis, Prentice Hall, England, UK.

Jain, C. K. 2004. Metal fractionation study on bed sediments of River Yamuna, India. Water Research. 38: 569-578.

Jena, V., Gupta, S., Dhundhel, R. S., Matic, N., Bilinski, F. S. and N. Devic. 2013 Determination of total heavy metal by sequential extraction fro soil. Inter. J. Res. Environ. Sci. Tech. 3 (1):35-38.

Kabata-Pendias, A. 2011. Trace Elements in Soils and Plants. CRC Press. http:// dx.doi.org/10.1201/b10158-25.

Kabata-Pendias, A. and B. Mukhrjee. 2007. Trace elements from soil to humans. Springer, Berlin, pp. 87-415.

Karak, T., Abollino, O., Bhattacharyya, P., Das, K.K. and K. Paul. 2011. Fractionation and speciation of arsenic in three tea gardens soil profiles and distribution of As in different parts of tea plant (Camellia sinensis L.). Chemosphere. 85: 948-960.
Kilmer, V.J. and T. Alexander. 1949 Methods of Making Mechanical Analysis of Soils. Soil Sci. 68: 15.

Liu, C. W., Lin, K. H. and Y. M. Kuo. 2003. Application of factor analysis in the assessment of ground water quality in a blackfoot disease area in Taiwan. Science of the Total Environment. 313:77-89.

Maiz, I., Arambarri, I., Garcia, R. and E. Millan. 2000. Evaluation of heavy metal availability in polluted soils by two sequential extraction procedures using factor analysis. Environmental Pollution.110: 3-9.

Mc Grath, S.P. and J. Loveland. 1992. The Soil Geochemical Atlas of England and Wales. Blackie Academic and Professional, London.

Mountouris, A., Voutsas, E. and D. Tassios. 2002. Bioconcentration of heavy metals in aquatic environments: The importance of bioavailability. Marine Pollution Bulletin. 44: 1136-1141.

Muller, G. 1969. Index of geoaccumulation in sediments of the Rhine River. J. Geol. 2: 108-118.

Nadimi-Goki, M., Mohammad, W., Claudio, B., Yoichiro, K., Gilmo, V. and A. Livia. 2014. Assessment of total soil and plant elements in rice-based production systems in NE Italy. Journal of Geochemical Exploration 147: 200-214.

Nagaraju, A. and S. Karimulla. 2002. Accumulation of elements in plants and soils in and around Nellore mica belt, Andhra Pradesh, India-A biogeachemical study. Environmental Geology. 41: 852-860.

Nicholson, G. 1984. Methods of Soil, Plant and Water Analysis. N.Z. Forest Service. F. R. I. Bulletin, 70.

Panda, U. C., Rath, P., Sundaray, S. K., Majumdar, S. and K.C. Sahu. 2006. Study of geochemical association of some trace metals in the sediments of Chilika lagoon-a multivariate statistical approach. Environmental Monitoring and Assessment. 123:125-150.

Parkman, R.H, Charnock, J.M, Livens, F.R. and J. Vaughan. 1998. A study of the interaction of strontium ions in aqueous solution with the surfaces of calcite and kaolinite. Geochimica et Cosmo-chimica Acta.62 (9): 1481-1492.

Perin, G., Craboledda, L., Lucchese, M., Cirillo, R., Dotta, L., Zanette, M. and A. Orio. 1985. Heavy metals speciation in the sediments of Northern Adriatic Sea-a new approach for environmental toxicity determination. In: Lekkas, T.D. (Ed.), Heavy Metal in the Environment 2, (pp. 454-456).

Picouet, C., Dupre, B., Orange, D. and M. Valladon. 2002. Major and trace element geochemistry in the upper Niger river (Mali): physical and chemical weathering rates and $\mathrm{CO} 2$ consumption.

Piper, C. S. 1950. Soil and Plant Analysis, Waite Agric. Res. Inst., Adelaide, S.A., Australia.

Qing, X., Yutong, Z. and L. Shenggao. 2015. Assessment of heavy metal pollution and human health risk in urban soils of steel industrial city (Anshan), Liaoning, Northeast China. Ecotoxicology and Environmental Safety. 120: 377- 385 . 
Rath, P., Panda, U. C., Bhatta, D. and C. Sahu. 2009. Use of sequential leaching, mineralogy, morphology and multivariate statistical technique for quantifying metal pollution in highly polluted aquatic sediments-a case study: Brahmani and Nandira Rivers, India. Journal of Hazardous Materials. 163: 632-644.

Reimann, C., Siewers, U., Tarvainen, T., Bityukova, L., Erikson, A., Gilucis, V., Gregorauskiene, V., Lukasev, V.K., Matinian, N.N. and A. Pasieczna. 2003. Agricultural Soils in Northern Europe: a Geochemical Atlas. Geologisches Jahrbuch Sonderhefte, Reihe D Heff SD5, Stuttgart.

Rudnick, R. and S. Gao. 2004. Composition of the continental crust. In: Rudnick, R. (Ed.), The crust. Elsevier Ltd, UK, pp. 1-64.

Salminen, R. 2005. Geochemical Atlas of Europe. Part I. Background Information, Methodology and Maps. Geological Survey of Finland. Electronic version http:// iwww.gsf.fi/pubil/foregsatlas.

Singh, P.K., Mohan, D., Singh, V.K., and A. Malik. 2005. Studies on distribution and fraction of heavy metals in Gomti river sediments - a tributary of the Ganges, India. Journal of Hydrology. 312:14-27.

Swarnalatha, K., Letha, J., Ayoob, S. and G. Nair. 2015. Risk assessment of heavy metal contamination in sediments of a tropical lake. Environmental Monitoring and Assessment.187:322.

Takeda A, Kimura K. and S. Yamasaki. 2004. Analysis of 57 elements in Japanese soils, with special reference to soil group and agricultural use. Geoderma. 119:291-307.

Tessier, P.G., Campbell, C. and M. Bisson. 1979. Sequential extraction procedure for speciation of particulate trace metals. Analyt. Chem. 51: 844- 851.

Towett, K., Shepherd, K., Tondoh, J., Winowiecki, L., Lulseged, L., Nyambura, M., Sila, A., T-G, Vagen. and G. Cadisch. 2015. Total elemental composition of soils in Sub-Saharan Africa and relationship with soil forming factors. 5: 157-168.

Tume, P., Bech, J. B., Reverter, F. C., Bech, J. D., Longan, L. D., Tume, L.E. and B. Sep?lveda. 2011. Concentration and distribution of twelve metals in Central Catalonia surface soils. Journal of Geochemical Exploration 109: 92-103.

Viers, J., Dupr, B. and J. Gaillardet. 2009. Chemical composition of suspended sediments in World Rivers: new insights from a new database. Sci. Total Environ. 407: 853-868.

Yanai, J., Okada, T. and H. Yamada. 2012. Elemental composition of agricultural soils in Japan in relation to soil type, land use and region. Soil Science and Plant Nutrition. 58: 1-10. 


\section{الملخص العربي}

السلوك البيئى لعنصر الاسترنشيوم فى بعض الار اضى المتاثرة بالاملاح عبر الساحل الشمالى الغربى

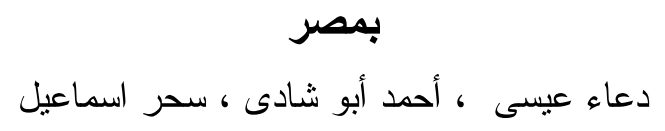

لمعامل التز اكم الجغر افى قد تم الحصول عليه مع عنصر

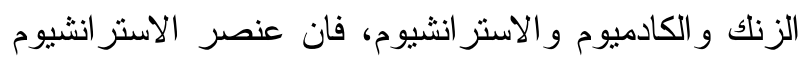

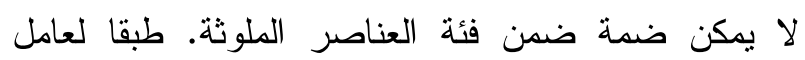
التلوث تم تصنف الاسنر انشيوم ضمن درجة العناصر ذات

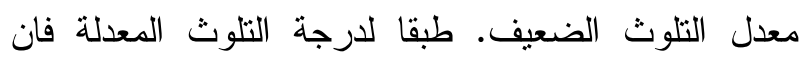
تركيزات عنصر الاسترانشيوم لا يمكن ادراجها ضمن ضلهن

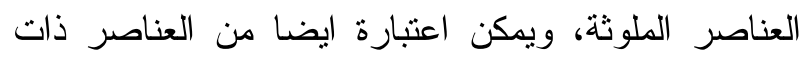

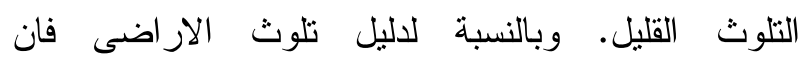

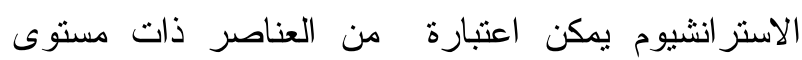
التلوث المنوسط. وقد سجلت اعلى درجات معدل التركم

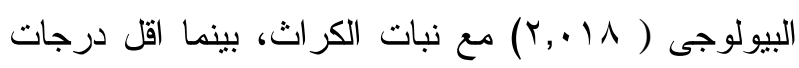

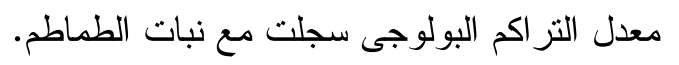

اجريت دراسة لتقييم مدى تلوث الاراضى المتاخمة

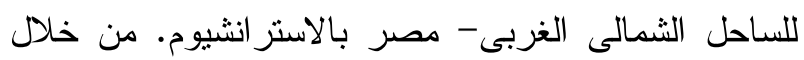
دراسة موشرات المخاطر مثل عامل التخصيب (EF) ومؤشر التزاكم الجغرافي (CF) و (CF) وعامل التلوث ودرجة التلوث (C) ودرجة التلوث ومؤشر تلوث التربة، بالاضافة الى تقييم المخاطر

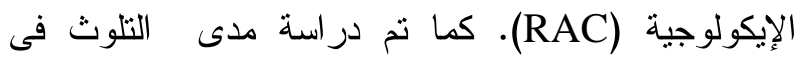

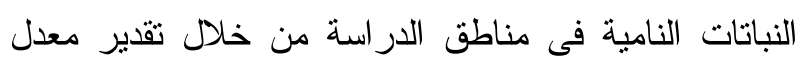
التزاكم البيولوجي (BAC) للاسترانشيوم فى لنى الطماطم و الكراث و الثعير و الزيتون و البرسيم و الذرة الرفيعة و التقاح

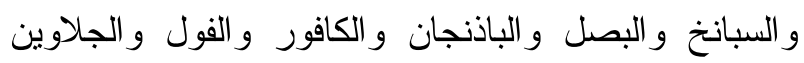

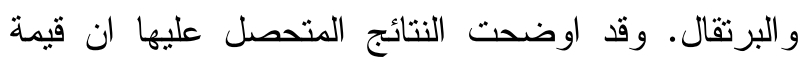
عامل التخصيب للاستر انشيوم وصلت لاعلى القيم بالمقارنة بالعناصر الاخرى الموجودة و على الرغم من ان اعلى قيم 